\title{
BALANCED SCORECARD: IS IT BENEFICIAL ENOUGH? A LITERATURE REVIEW
}

\author{
RATNANINGRUM1,2, * \\ Y. ANNI ARYANI ${ }^{1}$ \\ DODDY SETIAWAN ${ }^{1}$
}

Received: 12 July 2019 / Revised: 9 September, 19 December 2019 / Accepted: 26 December 2019 (C) 2020 Faculty of Business and Accountancy, University of Malaya. All rights reserved.

\section{A B S T R ACT}

Purpose of the Research: This study reviews and evaluates the development of research on the balanced scorecard.

Design/ Methodology/ Approach: This is a literature study of71 articles from 21 Scopus Q1 indexed journals. The issuance year was ignored, yet the search area was restricted to business, management, and accounting. The analysis is grouped into three parts, namely BSC in private sectors, BSC in public sectors, and criticism for BSC. In private sectors and SMEs, the theme is divided into benefits of BSC, implementations of BSC, limitations and other tools to improve BSC. Research finding: Although a large number of academics are sceptical about the relationship between BSC and organisational outcomes, BSC is widely used. Practitioner-oriented literature shows that it has useful values especially in improving organisational performance and strategy attainment. Based on the findings of empirical results in the private sector, SMEs, and the public sector, it can be inferred that the implementation status of the balanced scorecard shows a high level of success and minimal failure.

Theoretical contribution/ Originality: The BSC has limitations, yet these findings show that BSC is beneficial enough.

Practitioner/ Policy implication: The BSC remains worth considering for a performance management system.

Limitation/ Implication: This literature review is limited to specific quality ratings of the academic journals.

Type of article: Literature review

Keywords: Balanced Scorecard, Kaplan and Norton, Management Accounting, Literature Review JEL Classification: M21, M41

\section{Introduction}

This study reviews the literature on the balanced scorecard based on articles published in Scopus first-ranked (Q1) indexed journals. Since its introduction by Robert Kaplan and David Norton (KN) in 1992 (Kaplan \& Norton, 1992), there has been considerable attention from the management and business communities on the balanced scorecard (BSC). The BSC was introduced as an integrative device capable of encouraging and facilitating senior managers of organisations in the utilisation of non-financial information, where they may opt in to have nonfinancial measures driven largely by what is considered "strategic" considerations. In their opinion, managers will have the capability to deliver greater strategic performance when they are accommodated with this better

\footnotetext{
${ }^{1}$ Faculty of Economics and Business, Universitas Sebelas Maret, Surakarta, Jawa Tengah 57126, Indonesia

${ }^{2}$ Sekolah Tinggi Ilmu Ekonomi Trianandra Kartasura, Jawa Tengah 57163, Indonesia

* E-mail for corresponding author: ratnaningrumsolo@gmail.com
} 
information (Kaplan \& Norton, 1992). Initially, balanced scorecard was developed for private enterprises (Kaplan \& Norton, 1992). A few years after its introduction, many firms in the West admitted that they had applied this model (Speckbacher, Bischof, \& Pfeiffer, 2003). From merely a means of management reporting, BSC has grown into a strategic measure used by executive teams for strategy formulation, operation alignment, and communication with stakeholders, both internal and external (Gumbus \& Lyons, 2002).

The success of the BSC has been enormous, and companies all over the world widely adopt this method. Kurtzman (1997) mentioned that some of Kaplan and Norton's KPIs were employed by no less than 64 per cent of companies in order to assess their performance. Further, this comprehensive use was noticed by researchers who were then encouraged to form theories about BSC and test its effectiveness. This area of research is ongoing and BSC (see, for example, Atkinson, 2006) is deemed the dominant framework in the domain of performance management, despite the fact that the literature recognises its weaknesses. Until 1998, articles published concerning this field were typically normative and full of expectations and hopes (Johanson, Skoog, Backlund, \& Almqvist, 2006).

In BSC, a strategy map is used to depict the causal model of an organisation's strategy in a graphical representation (Kaplan \& Norton, 1996; Nørreklit, 2000). From this map, the internal processes undergone by an organisation to gain the result as it expected may be revealed (Kaplan \& Norton, 2004). However, some researchers contend that there is no method to develop such a model (Malmi, 2001; Speckbacher, Bischof, \& Pfeiffer, 2003). The struggle in observing the causal model of a strategy partly results from the limitation of the strategy map itself (Othman, 2008). The central idea of BSC is developing a causal model of the strategy, but as discovered by Davis and Albright (2004), 77 per cent of firms adopting BSC in the USA reportedly failed to accomplish this objective. This failure is confirmed in researches on BSC adoption in Finland, Austria, Malaysia, and Germany (Malmi, 2001; Othman, 2006; Speckbacher et al., 2003).

Even though its adoption has expanded, the implementation of BSC has yielded varied results, from success, no actual results, to being completely unsuccessful (For example Malagueño, Lopez, \& Gomez, 2018; Llah, 2017; Bento, Mertins, \& White, 2016). A growing body of literature is dedicated to identifying the limitations on BSC, specifically its concept (Neely et al., 2004; Nielsen, Lund, \& Thomsen, 2017, Masshingham, Masshingham, \& Dumai, 2018), application (Voelpel, Leibold, \& Eckhoff, 2006), and practice (Hoque, 2014). Such limitations may impair the effectiveness of BSC or lead companies to completely leave BSC to find alternatives for better performance measurement.

There have been numerous criticisms directed at BSC (Bessire \& Baker, 2005; 2004; Dinesh \& Palmer, 1998; Nørreklit, 2000, 2003; Nielsen, et. al.,2017). Some argue how it lacks norm of human relations in the implementation, whereas others highlight a tendency it creates to treat organisations to mechanistic systems from the analogue system (Bessire \& Baker, 2005; Dinesh \& Palmer, 1998). Intriguingly, although not surprising, issues brought up in articles about the BSC implementation are nothing unique to BSC. They are general to the change of management control (Johanson, et al., 2006). 
How BSC becomes static and overlooks the external environment is another concern noted by critics (Nørreklit, 2003; Voelpel, Leibold, \& Eckhoff, 2006). Those traits are related since this staticism appears somewhat on account of the internal focus of BSC. When the dynamism of the external environment is not taken into account when the thinking of BSC, it inclines towards creating measures that are separated from reality (Othman, 2008). Apart from the role of BSC in assisting organisations in the implementation of their strategies, they remain unable to cope with any changes that can influence such strategies. Inspired by the above, this study examines the benefits, implementation, limitations, and critique of the concept and practice of the BSC.

Following this section, section two presents the databases and methods used to map out the articles with the topic of the balanced scorecard. Section three categorises and analyses the result into three theme groups (BSC in private sector, $\mathrm{BSC}$ in the public sector, and criticism of BSC). In the private sector, the theme is divided into the benefit of BSC, implementation of BSC, limitation and other tools to improve BSC. Section four summarises and concludes the results.

\section{Method}

\subsection{Article Selection}

We identified articles with BSC topics published in Scopus first-ranked (Q1) indexed journals, as we focus on examining BSC literature published in highly qualified and reputable sources. The underlying basis for the analysis of Q1 journals owes to the fact that these journals are more qualified and have better classifications (Galindo et al., 2018), in addition to higher impact as confirmed by the SJR indicator (Ennas \& Di Guardo, 2015). In acquiring the articles, we conducted an online search at Scimago.com. The years of research were ignored to evaluate the development of the literature on BSC from the beginning BSC issue became material for discussion in journals which occupied Q1 until now. We limited the search area in business, management, and accounting, and categories in those fields (miscellaneous). This limitation was intended to discover the development of BSC literature, especially in the said domains. There were 72 journals categorised as Q1. We acquired 71 articles from 21 journals on the balanced scorecard. Table 1 displays the distribution of articles that satisfy the criteria in each journal.

Table 1. Distribution of Articles in Various Journals

\begin{tabular}{clcl}
\hline No. & Journals & $\begin{array}{c}\text { No. of } \\
\text { Papers }\end{array}$ & Author(s) \\
\hline 1 & The Accounting Review & 5 & $\begin{array}{l}\text { Banker et al. (2004); Cheng and Humphreys } \\
\text { (2012); Lipe and Salterio (2000); Tayler (2010); } \\
\text { Itner (2003) }\end{array}$ \\
2 & $\begin{array}{l}\text { Journal of Accounting } \\
\text { Research }\end{array}$ & 3 & $\begin{array}{l}\text { Bude (2007); Chen, et. al (2016); Ding and } \\
\text { Beaulieu (2011) }\end{array}$ \\
Accounting, Organisations, & 1 & $\begin{array}{l}\text { Nørreklit (2003) } \\
\text { and Society } \\
\text { Critical Perspective on }\end{array}$ \\
Accounting & 4 & $\begin{array}{l}\text { Bessire and Bakker (2005); Lawrence and } \\
\text { Sharma (2002); Hoque (2003); Upton and } \\
\text { Arrington (2012) }\end{array}$
\end{tabular}


Table 1. Continued

\begin{tabular}{|c|c|c|c|}
\hline No. & Journals & $\begin{array}{l}\text { No. of } \\
\text { Papers }\end{array}$ & Author(s) \\
\hline 5 & $\begin{array}{l}\text { Accounting, Auditing, and } \\
\text { Accountability Journal }\end{array}$ & 2 & Johanson et al. (2006); Modell (2009) \\
\hline 6 & $\begin{array}{l}\text { Contemporary Accounting } \\
\text { Research }\end{array}$ & 2 & $\begin{array}{l}\text { Busco and Quattrone (2015); Cooper and Qu } \\
\text { (2017) }\end{array}$ \\
\hline 7 & $\begin{array}{l}\text { Management Accounting } \\
\text { Research }\end{array}$ & 5 & $\begin{array}{l}\text { Davis and Albright (2004); Malmi (2001); } \\
\text { Speckbacher et al. (2003); Ax and Bjørnenak } \\
\text { (2005); Nørreklit, H. (2000) }\end{array}$ \\
\hline 8 & $\begin{array}{l}\text { Meditari Accounting } \\
\text { Research }\end{array}$ & 1 & Vermaak and Cronje (2001) \\
\hline 9 & $\begin{array}{l}\text { Measuring Business } \\
\text { Excellence }\end{array}$ & 10 & $\begin{array}{l}\text { Basu et al. (2009); Jayashree and Hussain } \\
\text { (2011); Lim and Chye (2001); Rich (2007); } \\
\text { Urrutia and Erricson (2005); Marr and Adams } \\
\text { (2004); Ahn (2005); Wongrassamee (2003); } \\
\text { Ahn (2005); Gurd and Ifandoudas (2014) }\end{array}$ \\
\hline 10 & Journal of Intellectual Capital & 6 & $\begin{array}{l}\text { Wu (2005); Bose (2007); Mouritsen et al. } \\
\text { (2005); Voelpel (2006); Nielsen et al. (2017); } \\
\text { Massingham et al. (2018) }\end{array}$ \\
\hline 11 & Management Decisions & 4 & $\begin{array}{l}\text { Atkinson (2006); Llach et al. (2017); Othman } \\
\text { (2006); Dinesh and Palmer (1998) }\end{array}$ \\
\hline 12 & $\begin{array}{l}\text { Journal of Small Business } \\
\text { Management }\end{array}$ & 1 & Gumbus and Lussier (2006) \\
\hline 13 & $\begin{array}{l}\text { Business Process } \\
\text { Reengineering and } \\
\text { Management }\end{array}$ & 1 & Letza (1996) \\
\hline 14 & $\begin{array}{l}\text { International Journal of } \\
\text { Productivity and } \\
\text { Performance Management }\end{array}$ & 12 & $\begin{array}{l}\text { Barnabe (2011); Valmohammadi (2011); } \\
\text { Behery et al. (2014); Chen et al. (2008); Lawrie } \\
\text { and Cobbold (2004); Perkins et al. (2014); } \\
\text { Schneider and Vieira (2010); Thakkar (2007); } \\
\text { Gurd and Gao (2007); Othman (2008); Perkins } \\
\text { and Remmers (2014); Moullin (2017) }\end{array}$ \\
\hline 15 & $\begin{array}{l}\text { International Journal of } \\
\text { Hospitality Management }\end{array}$ & 2 & Elbanna et al. (2015); Kang et al. (2015) \\
\hline 16 & Journal Business Ethics & 2 & $\begin{array}{l}\text { Bento et al. (2016); Hansen \&Schalttegger } \\
\text { (2016) }\end{array}$ \\
\hline 17 & $\begin{array}{l}\text { Journal of Knowledge } \\
\text { management }\end{array}$ & 1 & Hu et al. (2015) \\
\hline 18 & $\begin{array}{l}\text { Total Quality Management \& } \\
\text { Business Excellence }\end{array}$ & 3 & $\begin{array}{l}\text { Andjelkovic and Dahlgaard (2013); Chiang } \\
\text { and Lin (2009); Garengo and Biazzo (2012) }\end{array}$ \\
\hline 19 & Total Quality Management & 4 & Dror (2008); Chang et al. (2008); \\
\hline 20 & Small Business Economics & 1 & Malagueño et al. (2018) \\
\hline 21 & $\begin{array}{l}\text { Family Business Review } \\
\text { Total }\end{array}$ & $\begin{array}{c}1 \\
71\end{array}$ & Craig and Moores (2005) \\
\hline
\end{tabular}

Table 2. Classification of literature on Balanced Scorecard

\begin{tabular}{clrll}
\hline No. & Author & Year & Method & Theme \\
\hline 1 & Ahn & 2005 & Case study & $\begin{array}{l}\text { Individualised BSC } \\
2\end{array}$ \\
Asan and Tanyas & 2007 & $\begin{array}{l}\text { Literature } \\
\text { review }\end{array}$ & $\begin{array}{l}\text { Integrating BSC and HoshinKanri in higher } \\
\text { education }\end{array}$ \\
3 & Atkinson & 2006 & $\begin{array}{l}\text { Literature } \\
\text { review }\end{array}$ & Role of BSC \\
& &
\end{tabular}


Table 2. Continued

\begin{tabular}{|c|c|c|c|c|}
\hline No. & Author & Year & Method & Theme \\
\hline 4 & Ax and Bjørnenak & 2005 & $\begin{array}{l}\text { Literature } \\
\text { review }\end{array}$ & BSC and diffusion of innovations \\
\hline 5 & Banker et al. & 2004 & Experiment & Conditional use of strategy-linked measures \\
\hline 6 & Basu et al. & 2009 & Case study & Application of BSC in infrastructure project \\
\hline 7 & Behery et al. & 2014 & $\begin{array}{l}\text { Qualitative case } \\
\text { study }\end{array}$ & $\begin{array}{l}\text { Performance management system in Fast- } \\
\text { Growth SMEs }\end{array}$ \\
\hline 8 & Bento et. al. & 2016 & Experiment & $\begin{array}{l}\text { Financial bias in appraisal when CSR } \\
\text { measures are used in BSC }\end{array}$ \\
\hline 9 & Bernabe & 2011 & Case study & Development of dynamics BSC \\
\hline 10 & $\begin{array}{l}\text { Bessire and } \\
\text { Bakker }\end{array}$ & 2005 & Critical Review & French Tableau de bord and BSC \\
\hline 11 & Bose and Thomas & 2007 & Case study & $\begin{array}{l}\text { BSC for better performance of intellectual } \\
\text { capital }\end{array}$ \\
\hline 12 & Budde & 2007 & $\begin{array}{l}\text { Literature } \\
\text { review }\end{array}$ & Incentive effect of BSC \\
\hline 13 & Busco & 2015 & $\begin{array}{l}\text { Literature } \\
\text { review }\end{array}$ & $\begin{array}{l}\text { Continuous unfolding of rationales for the } \\
\text { use of BSC }\end{array}$ \\
\hline 14 & Chang et al. & 2008 & Case Study & BSC in large hospital \\
\hline 15 & Chen et al. & 2016 & Experiment & $\begin{array}{l}\text { Visual attention in managerial judgement } \\
\text { during BSC evaluation }\end{array}$ \\
\hline 16 & Chen et. al & 2008 & Case study & Performance analysis using DEA and BSC \\
\hline 17 & $\begin{array}{l}\text { Cheng and } \\
\text { Humpreys }\end{array}$ & 2012 & Experiment & $\begin{array}{l}\text { Causal linkages between strategic objectives } \\
\text { in the strategy map and performance } \\
\text { measurement }\end{array}$ \\
\hline 18 & Chiang and Lin & 2009 & Survey & Integration BSC and DEA \\
\hline 19 & Cooper and Qu & 2017 & Interview & Popularising idea of BSC \\
\hline 20 & Craig and Moores & 2005 & $\begin{array}{l}\text { Action research } \\
\text { project }\end{array}$ & $\begin{array}{l}\text { Adoption of BSC strategy in family business } \\
\text { context }\end{array}$ \\
\hline 21 & $\begin{array}{l}\text { Davis and } \\
\text { Albright }\end{array}$ & 2004 & Experiment & Effect of BSC on financial performance \\
\hline 22 & $\begin{array}{l}\text { Dinesh and } \\
\text { Palmer }\end{array}$ & 1998 & $\begin{array}{l}\text { Literature } \\
\text { review }\end{array}$ & $\mathrm{MBO}$ and BSC \\
\hline 23 & $\begin{array}{l}\text { Ding and } \\
\text { Beaulieu }\end{array}$ & 2011 & Experiment & Mood congruency bias \\
\hline 24 & Dror & 2008 & $\begin{array}{l}\text { Literature } \\
\text { review }\end{array}$ & BSC in an individual organisation \\
\hline 25 & Elbanna et al. & 2015 & Survey & $\begin{array}{l}\text { A theoretical construct development of BSC } \\
\text { and its empirical validation }\end{array}$ \\
\hline 26 & $\begin{array}{l}\text { Garengo and } \\
\text { Biazzo }\end{array}$ & 2012 & $\begin{array}{l}\text { Action research } \\
\text { project }\end{array}$ & $\begin{array}{l}\text { Performance Measurement System through } \\
\text { BSC for SMEs }\end{array}$ \\
\hline 27 & Gumbus & 2006 & Case study & BSC in SMEs \\
\hline 28 & $\begin{array}{l}\text { Gurd and } \\
\text { Ifandoudas }\end{array}$ & 2014 & Action research & Usefulness of agility focused BSC \\
\hline 29 & Gurd and Gao & 2007 & $\begin{array}{l}\text { Literature } \\
\text { review }\end{array}$ & BSC in the health care sector \\
\hline 30 & $\begin{array}{l}\text { Hansen and } \\
\text { Schaltegger }\end{array}$ & 2016 & $\begin{array}{l}\text { Literature } \\
\text { review }\end{array}$ & Sustainability BSC \\
\hline 31 & Hoque & 2003 & $\begin{array}{l}\text { Literature } \\
\text { review }\end{array}$ & TQM and BSC \\
\hline 32 & $\mathrm{Hu}$, et. al. & 2015 & Case study & Analytic Network Process (ANP) and BSC \\
\hline 33 & Ittner et al. & 2003 & Survey & Overreliance on financial measures \\
\hline
\end{tabular}


Table 2. Continued

\begin{tabular}{|c|c|c|c|c|}
\hline No. & Author & Year & Method & Theme \\
\hline 34 & $\begin{array}{l}\text { Jayashree and } \\
\text { Hussain }\end{array}$ & 2011 & $\begin{array}{l}\text { Literature } \\
\text { review }\end{array}$ & BSC and aligning change deployment \\
\hline 35 & Johanson et al. & 2006 & Critical review & Balancing dilemmas of BSC \\
\hline 36 & Kang, et. al. & 2015 & Survey & The Sustainability BSC (SBSC) and CSR \\
\hline 37 & $\begin{array}{l}\text { Lawrence and } \\
\text { Sharma }\end{array}$ & 2002 & Case Study & BSC \& TQM in University setting \\
\hline 38 & $\begin{array}{l}\text { Lawrie and } \\
\text { Cobbold }\end{array}$ & 2004 & $\begin{array}{l}\text { Literature } \\
\text { review }\end{array}$ & $\begin{array}{l}\text { The changes to the definition of what } \\
\text { constitutes of BSC }\end{array}$ \\
\hline 39 & Letza & 1996 & Case study & $\begin{array}{l}\text { Design and implementation BSC in three } \\
\text { company }\end{array}$ \\
\hline 40 & Ling and Chye & 2001 & Survey & strategic performance measurement by BSC \\
\hline 41 & Lipe and Salterio & 2000 & Experiment & Common measure bias \\
\hline 42 & Llah et al. & 2017 & Survey & Further research on the BSC model \\
\hline 43 & Malagueño et al. & 2018 & Survey & Balance scorecard in SMEs \\
\hline 44 & Malmi & 2001 & Interviews & Applied BSC in Finland \\
\hline 45 & Marr and Adams & 2004 & $\begin{array}{l}\text { Literature } \\
\text { review }\end{array}$ & BSC and intangible asset \\
\hline 46 & $\begin{array}{l}\text { Mashingham et } \\
\text { al. }\end{array}$ & 2018 & $\begin{array}{l}\text { Conceptual } \\
\text { review }\end{array}$ & $\begin{array}{l}\text { A new learning and growth perspective for } \\
\text { the BSC }\end{array}$ \\
\hline 47 & Mehralian et al. & 2017 & Survey & Relationship TQM with BSC \\
\hline 48 & Modell & 2009 & Case study & $\begin{array}{l}\text { Experimenting with TQM and BSC in } \\
\text { governance }\end{array}$ \\
\hline 49 & Moullin & 2015 & Case study & $\begin{array}{l}\text { Improving and evaluating performance } \\
\text { with the public sector scorecard }\end{array}$ \\
\hline 50 & Mouritsen et al. & 2005 & $\begin{array}{l}\text { Literature } \\
\text { review }\end{array}$ & $\begin{array}{l}\text { The differences between TQM and } \\
\text { Intellectual Capital }\end{array}$ \\
\hline 51 & Nielsen et al. & 2017 & Critical review & $\begin{array}{l}\text { Killing the balanced scorecard to improve } \\
\text { internal disclosure }\end{array}$ \\
\hline 52 & Nørreklit & 2003 & Critical review & Rhetorical analysis of BSC \\
\hline 53 & Nørreklit & 2000 & Critical review & Cause and effect of four perspective of BSC \\
\hline 54 & Othman & 2006 & Survey & $\begin{array}{l}\text { BSC adoption experience among } \\
\text { Malaysian companies }\end{array}$ \\
\hline 55 & Othman & 2008 & $\begin{array}{l}\text { Literature } \\
\text { review }\end{array}$ & Effectivity of BSC \\
\hline 56 & $\begin{array}{l}\text { Perkins and } \\
\text { Remmers }\end{array}$ & 2014 & $\begin{array}{l}\text { Literature } \\
\text { review }\end{array}$ & Subsets of BSC into three generations \\
\hline 57 & Perramon et al. & 2016 & Survey & Create value through BSC \\
\hline 58 & $\begin{array}{l}\text { Andjelkovic and } \\
\text { Dahlgaard }\end{array}$ & 2013 & Survey & $\begin{array}{l}\text { Combined roadmap of BSC and EFQM } \\
\text { model }\end{array}$ \\
\hline 59 & Rich & 2007 & Experiment & $\begin{array}{l}\text { Human interpretation of performance } \\
\text { management using BSC }\end{array}$ \\
\hline 60 & $\begin{array}{l}\text { Schneider and } \\
\text { Vieira }\end{array}$ & 2010 & $\begin{array}{l}\text { Action research } \\
\text { study }\end{array}$ & $\begin{array}{l}\text { Implementation of BSC at a wind farm } \\
\text { company }\end{array}$ \\
\hline 61 & Soderberg et al. & 2011 & Survey & A taxonomy of BSC \\
\hline 62 & Speckbacher et al. & 2003 & survey & Analysis on The Implementation of BSC \\
\hline 63 & Tayler & 2010 & Experiment & Involvement in scorecard implementation \\
\hline 64 & Thakkar et al. & 2006 & Interview & $\begin{array}{l}\text { Development of BSC: An integrated } \\
\text { approach of ISIM and ANP }\end{array}$ \\
\hline 65 & $\begin{array}{l}\text { Upton and } \\
\text { Arrington }\end{array}$ & 2012 & Experiment & $\begin{array}{l}\text { Racial prejudice in BSC performance } \\
\text { evaluation }\end{array}$ \\
\hline
\end{tabular}


Table 2. Continued

\begin{tabular}{|c|c|c|c|c|}
\hline No. & Author & Year & Method & Theme \\
\hline 66 & $\begin{array}{l}\text { Urrutia and } \\
\text { Eriksen }\end{array}$ & 2005 & $\begin{array}{l}\text { Literature } \\
\text { review }\end{array}$ & $\begin{array}{l}\text { BSC in Spanish private health care } \\
\text { management }\end{array}$ \\
\hline 67 & $\begin{array}{l}\text { Valmohammadi } \\
\text { and Servati }\end{array}$ & 2011 & Case study & $\begin{array}{l}\text { Combined approach of BSC and statistical } \\
\text { method }\end{array}$ \\
\hline 68 & $\begin{array}{l}\text { Vermaak and } \\
\text { Cronje }\end{array}$ & 2001 & Survey & BSC in accounting education \\
\hline 69 & Voelpel et al. & 2006 & Critical review & Major problem areas of BSC \\
\hline 70 & $\begin{array}{l}\text { Wongrassamee et } \\
\text { al. }\end{array}$ & 2003 & Critical review & $\begin{array}{l}\text { Similarities and differences betweenBSC } \\
\text { and European Foundation for Quality } \\
\text { Model (EFQM) }\end{array}$ \\
\hline 71 & $\mathrm{Wu}$ & 2005 & Case study & Integration BSC and intellectual capital \\
\hline
\end{tabular}

Table 3. The Categories of Methods Used by Researcher

\begin{tabular}{clcc}
\hline No & \multicolumn{1}{c}{ Methodology } & Number of Papers & Percentage \\
\hline 1 & Literature Review & 17 & 23.9 \\
2 & Case Study & 15 & 21.1 \\
3 & Experiment & 10 & 14.08 \\
4 & Survey & 15 & 21.1 \\
5 & Critical Review & 7 & 9.86 \\
6 & Conceptual Review & 1 & 1.4 \\
7 & Action Research & 3 & 4.2 \\
8 & Interviews & 3 & 4.2 \\
& Total & 71 & 100 \\
\hline
\end{tabular}

Table 4. Organisation/Setting of the Empirical Research

\begin{tabular}{clcc}
\hline No & \multicolumn{1}{c}{ Setting } & Number of Papers & Percentage \\
\hline 1 & Private Sector & 37 & 80 \\
2 & Public Sector & 5 & 11 \\
3 & SMEs & 3 & 7 \\
& Total & 45 & 100 \\
\hline
\end{tabular}

\subsection{Articles Identification}

Subsequently, we classified the articles by the author alphabetically, the method used, and the theme. The classification of the articles is shown in Table 2. We identified the categories of the method used by the researcher in each article. Overall, there were 71 articles, 45 of which employing empirical research and the remaining applying critical review, literature review, and conceptual review. The details of the methods used, and the setting of empirical research are set out in tables below. We obtained 71 articles, 45 of which were classified as empirical researches. From these empirical researches, 37 articles (80 per cent) were made by employing the setting of the private sector and three articles ( 7 per cent) of SMEs.

\section{Discussion}

\subsection{Balanced Scorecard in Private Sector and SMEs}

We grouped the articles created by occupying the setting of the private sector and SMEs based on the reviews of benefits, implementations, limitations and other tools to improve BSC, as discussed below. 


\subsubsection{Benefit of Balance Scorecard}

BSC was originally used to measure performance (Kaplan \& Norton, 1992). When using BSC for such a purpose, firms focused on finance, customer, internal process, and learning and growth metrics (Kaplan \& Norton, 2001). With these metrics measured, firms can identify all significant qualities of their strategy and improve partnership and teamwork continuously. In BSC, financial metrics are the most substantial measure of a firm's performance. Ding and Beaulieu (2011) found that in balanced scorecard, financial incentives can serve as a motivation for decision-makers to correct mood congruency biases. Whereas, David and Albright (2004) saw superior financial performances in branches that implement BSC in comparison with those that do not. Apart from its deficiency in the empirical testing of its benefits (Nørreklit, 2000; Speckbacher et al., 2003), it can be said that balanced scorecard is a framework commonly applied in terms of performance management (Marr \& Schiuma, 2003). The balanced scorecard is applied extensively as a tool for organisations to measure performance and implement strategy (Soderberg, Kalagnanam, Sheehan, \& Vaidyanathan, 2011). Research has demonstrated that managers, either within or across organisations, may view the BSC differently, simplifying that the systems of performance measurement put into practice in organisations may be different from the construct proposed by Kaplan \& Norton. Perkins, Grey and Remmers (2014) provided a classification for the different version of BSC, allowing a more distinctive analysis of BSC as a performance management tool. BSC measures internal processes as well to focus on the operations that improve customer satisfaction, also to highlight innovation and learning so that the employees' skill may improve and superior process of internal business can be achieved (Bose \& Thomas, 2007). After analysing the mediating effect of internal processes and customers, Llach, Bagur, Perramon, and Marimon (2007) found that both contribute significantly to financial results. Consistent with the spirit of BSC, non-financial performance measures appear to take a leading role in the financial institution valuation (Wang, 2005). Via BSC, manufacturing plants can perform better after strategically associating their corporate objectives with their systems of performance measurement (Ling \& Chye, 2001).

The use of BSC is a measure suitable for understanding the value creation through investing in human resources (Perramon, Rocafort, Bagur, \& Llach, 2016). Also, Bose and Thomas (2007) signify the importance of learning and growth for strategic management so that the performance of intellectual capital may be identified, improved, and made better. An increasing intellectual capital is paramount to establish innovative product designs, production, distribution, and promotion in addition to enhance the market value of an organisation exceeding the value of its tangible asset base. Another common use of BSC is project management. Basu, Little, and Millard (2009) contended that for project managers, the principal aspect of BSC is creating tangible performance measures from projects tasks. In this way, project managers may be assisted in monitoring the progress of project performance and also identifying tasks that are overdue, tasks that demand greater resources and skills, and knowledge that is necessary to perform specific tasks. 
The BSC framework, including performance measures classified by the perspective of the scorecard and strategic objectives provided in the form of a strategy map, may likely improve the strategic awareness of managers, thus supporting them in performing evaluation and revision of organisational strategies (Kaplan \& Norton, 2001). Apart from the benefits claimed, minimum empirical research has examined the roles of the BSC framework in facilitating decisions (Sprinkle \& Williamson, 2007). For example, Cheng and Humpreys (2012) found that the BSC framework has diverged decision-facilitating impacts on strategic judgements of managers. Tayler (2010) concluded that constructing scorecard perspectives as a causal chain reduces motivated reasoning biases when managers evaluate their strategic initiatives by taking into account internal information.

Integrated and strategic management tools introduced by BSC can be used to measure and review changes and to manage the change process (Jayashree \& Hussain, 2011). Moreover, BSC has the capability of addressing the key problem connected with the implementation of strategy, including communication, the function of middle managers, and integration with the existing control system (Atkinson, 2006). Apart from some judgements and queries regarding the balanced scorecard approach, many of them appear to serve as issues of practical application, not as fundamental flaws (Atkinson, 2006). There is evidence showing the maturing approach taken by organisations to implement a scorecard (Speckbacher et al., 2003), and that there is more and more guidance on constructing measures (Kaplan \& Norton, 2001, 2004).

\subsubsection{Implementation of Balanced Scorecard}

The effects of BSC on organisational performance in several empirical studies of articles reviewed in this study have different levels of clarity in terms of the way they were assessed and reported. From 40 identified empirical researches in private sector and SMEs, there are 12 articles (30 per cent) of these empirical studies which illustrated increases in the financial performance measures following the adoption of BSC, comprising Davis and Albright (2004), Ling and Chye (2001), Lopez-Valeiras, and Gomez-Conde (2018), Craig and Moores (2005); Perramon et al., (2016), Wu (2005), Garengo and Biazzo (2012), Gumbus and Lussier (2006), Chang (2008), Chiang and Lin (2009), Andjelcovic and Dahlgaard (2013), and Gurd and Ifandoudas (2014).

On the other hand, five other articles (12.5 per cent) reported failure in the above matter, comprising of Behery (2014), Bento (2016), Letza (2004), Malmi (2001), and Speckbacher et al. (2003). The remaining 23 articles (57.5 per cent) are less representative as the methodology, and the data collection are not sufficiently detailed. In other words, there is limited evidence demonstrating the success of BSC implementation. To date, studies examining the association of non-financial measures and financial performance measures have concluded various results. As one possible cause, Davis and Albright (2004) believed that this may be attributed to the minimum coherent linkage between the measures selected for the performance system and the financial measure of interest being targeted.

The implication of the use of the balanced scorecard (BSC) has been studied empirically mostly in large firms. Advocates of BSC have advised that SMEs might 
benefit largely from the use of BSC (Kaplan and Norton, 1996). However, previous findings are not easily applicable to the literature of small business (Malagueño et al., 2018). The analysis of the studies on performance measurement systems for SMEs reveals a glaring contradiction: on one hand, there is evidence that these enterprises encounter difficulties in rationalising their operational practices as well as strategic processes. On the other hand, there are methodologies proposed by scholarly literature for the implementation of such a system based upon a topdown approach so that the strategies applied are actionable with minimum consideration to the tendency of small enterprises disregard the formalisation of their strategic choices (Garengo \& Biazzo, 2012).

From 201 SMEs surveyed in Spain, Malagueño et al. (2018) exposed that firms implementing BSC for feedforward control obtained better performance in their finance and they could present exploitative innovation in higher levels. Also, BSC is used by more than half of 1000 companies to improve their performance, and the benefit of this management tool can be gain by SMEs as well as it is exceptionally different but functional for them (Gumbus \& Lussier, 2006). As for family business, they can take benefit of a BSC strategy map to professionalise their management (Craig \& Moores, 2005). Dror (2008) proposed a methodological approach based on Quality Function Deployment (QFD) to improve the implementation of BSC in individual organisations. He found that BSC initiatives are also already present in Fast-Growth SMEs (FGSMEs). However, such initiatives are not clearly linked nor directed towards the effective implementation of the BSC system.

As performance management systems, balanced scorecard and intellectual capital incorporate financial and non-financial indicators, where both are combined closely to the firm's strategy. There are remarkably different notions of strategy that become the ground for the balanced scorecard and the intellectual capital approach. They cause the behaviour of such comprehensive performance management systems to vary greatly in terms of their proximity one and another (Mouritsen, Thorsgaard, \& Bukh, 2005). By using BSC, the creation, formation, and measurement of Strategic Intellectual Capital (SIC) are possible. It also enhances the reporting for SIC; BSC's financial, customer, internal process, and growth and learning perspectives can reinforce the management of IC $(\mathrm{Wu}, 2005)$. Bose and Thomas (2007) provided an example of a BSC-implementing company that can deal with the requirement of investing in knowledge and management skills by discussing how a newly appointed CEO of The Foster's Brewing Group handled their declining performance by several initiatives, including the adoption of balanced scorecard approach for the management.

In Sweden, other administrative innovations have been added to supplement the original BSC, which has also been accommodated to adapt with the on-going business culture so that it may create a potentially more attractive set of elements. From a certain point of view, this serves as a mode-setting process influential in the diffusion of BSC (Ax \& Bjørnenak, 2005). In the hotel context, Elbanna, Eid and Kamel (2015) sought to develop a customised organisational performance scale with particular emphasis on BSC perspectives. The findings suggest that managers do make a meaningful distinction between the five aspects of hotel performance. In project management, when compared with operation 
management, the application of balanced scorecard concept by Kaplan and Nortonis less common (Basu et al., 2009). Systematic new evidence was found by Speckbacher et al. (2003) on the application of BSC. Their classification of BSC types were intended (1) to enable theoretical discussion of BSC concept in a more structured and concrete manner and (2) acquire a systematic empirical overview of how the BSC concept is implemented in companies.

\subsubsection{Limitation and Another Tool to Improve Balanced Scorecard}

Most academics have accepted BSC, and numerous practitioners in industry have adopted this approach (Mistry, 2003). Nevertheless, it has major limitations as discussed in the literature (Othman, 2006). The deficiency of formal methodologies applied, and subjective measures often lead to short-term financial measures as a focus (Chiang \& Lin, 2009). Also, Dinesh and Palmer (1998) found that partial implementation would still be a problem for a balanced scorecard. Not only is BSC a relatively complex, it is also a costly measurement system. How cognition affects the use of BSC needs to be acknowledged in order to understand that BSC's potential benefits can be limited by cognitive capabilities and characteristics of managers, for example, the focus on standard measures impairs how a scorecard is hold and implemented by each business that uniquely captures its strategy as it becomes one of the primary benefits of BSC to embrace (Lipe \& Salterio, 2000). Under a complete verification, a balanced scorecard that is properly designed can entirely align the interests of owners and employees. This is possible with the help of an explicit contract. From the studies from field and experimental accounting on the BSC application to evaluate performance, there is evidence regarding its limitation, i.e. judgemental effects (Lipe \& Salterio, 2000; Banker \& Cheng, 2012), and subjectivity (Ittner, Larcker, \& Meyer, 2003). It is also found that the measures in the scorecard are not considered equally by managers (Rich, 2007).

Change is needed in the BSC because, as Nielsen et al. (2017) argue, the BSC is "dead" and needs to be replaced with new methods of intangible asset disclosures (IAD). With the methodical improvement introduced by the development of BSC, this approach is promising towards the establishment of individualised BSC. It is evident that such an approach requires elaboration so that it presents a more thorough procedure (Ahn, 2005). At wind farm organisations, the improvement of BSC concept is possible through customisation of the four typical perspectives, by adding other perspectives, such as suppliers, community, government, or others alike, that encourage awareness about stakeholders (Schneider \& Vieira, 2010). With a new perspective of learning and growth for the balanced scorecard (BSC) which covers more specific measures of integrated thinking and value creation, integrated reporting can be further improved (Mashingham et. al., 2018).

To improve the limitations of BSC and provide more useful information for managers, another tool can be integrated or combined with BSC, for example integration of BSC and EFQM (European Foundation for Quality Management) (Andjelcovic \& Dahlgaard, 2013; Wongrassamee, Simmons, and Gardiner 2003), Analytic network process (ANP) and BSC (Hu, Wen, \& Yan, 2015), TQM and BSC (Hoque, 2003; Mehralian, Nazari, Nooriparto, \& Rasekh, 2017), statistical methods and BSC (Valmohammadi \& Servati, 2011). DEA and BSC (Chiang \&Lin, 2009; Chen, Chen, \& Peng, 2008). Wongrassamee, Simmons, and Gardiner (2003) 
suggested that the key factor for success in applying EFQM and BSC to an organisation is correlated to the matter of how to decide adequate measures. For TQM-adopting firms, they will deal with this oversight. As a result, employee satisfaction will be improved and eventually so too will firm performance (Hoque, 2003), while TQM implementation can positively influence BSC and its four perspectives (Mehralian, Nazari, Nooriparto, \& Rasekh, 2017).

Thakkar, Deshmukh, Gupta and Shankar (2007) suggested that the use of Interpretive Structural Modelling (ISIM) and Analytic Network Process (ANP) as a mixed approach of cause and effect can resolve a number of the deficiencies in terms of BSC development in accordance with the real case found in a company. To promote strategic decision-making, it is possible to use system dynamics modelling principles to manage some limitations of the original BSC framework in a positive manner (Barnabe, 2011). Together, statistical methods and BSC can help organisations to plan and execute a system with sound performance (Valmohammadi \& Servati, 2011). Chiang and Lin (2009) tried to formulate an integrated framework where the basic concepts of balance scorecards (BSC) and data envelope analysis (DEA) are embraced for measurement. The result proved that BSC and DEA complete one another (Chiang \& Lin, 2009) and generate measures of technical efficiency for Taiwanese banks (Chen, Chen, \& Peng, 2008). Being the heart of an organisation's focus, agility can be achieved through a modified balanced scorecard system (Gurd \& Ifandoudas, 2014). This modification can be introduced into the original BSC by explicit consideration of environmental, social, or ethical issues, which is often known as sustainability balanced scorecard (SBSCs). Viewing the Sustainability Balanced Scorecard (SBSC) as a concept to assess the perceived importance of relationships between CSR and business performances, Kang, Chiang, Huangthanapan, \& Downing (2015) emphasised that CSR has a significant influence on BSC. Hansen and Schaltegger (2016) observed that modifications with sustainability orientation of BSC architecture are motivated by instrumental, social/political, or normative theoretical perspectives, capable of being mapped with generic SBSC architectures typology. Bento, et al. (2016) examine the use of CSR measures in BSC from the perspective of ideology, concluding that when CSR measures are used in BSC, there is a financial bias in decisions on appraisal and bonus.

\subsection{Balanced Scorecard in the Public Sector}

We obtained 45 articles as empirical research, five of which were made by employing the setting of the public sector. 2 (40 per cent) out of these five researches reported success in the adoption of BSC, i.e. Modell (2009) and Moullin (2015). Whereas, only 1 (20 per cent) of those five reported otherwise, i.e. Lawrence \& Sharma (2002). The original BSC (Kaplan \& Norton, 1992) has four perspectives (financial, customer, internal business process and learning and growth). Over time, other perspectives were included, such as sustainability (Brignall, 2002). In the development of the literature, Kaplan and Norton (2001) introduced a perspective called "mission" for non-profit organisations. The performance of non-profit organisations cannot be measured by financial indicators, instead by their effectiveness in providing benefits to constituents. For non-profit organisations, modifications must be made to BSC so that it includes a mission 
perspective (Urrutia \& Ericson, 2005). Having proved successful in respect of nonprofit organisations (Kaplan \& Norton, 1996, 2001), the BSC should also serve as a management technique with a similar value in the field of accounting education. Vermaak and Cronje (2001) supported the potential applicability of the balanced scorecard as an instrument to guide, stimulate, and sustain efforts of planning and improvement in such an environment. Health care sector also receives advantages from balanced scorecard as it is evident to be strategic performance measurement systems (Gurd \& Gao, 2007), as demonstrated by the successful development and implementation of BSC at hospitals in Taiwan (Chang, Tung, Huang, \& Yang, 2008). In the UK, in order to help organisations, improve outcomes for service users and stakeholders without increasing overall cost, the Public Sector Scorecard (PSS) adapted and extended the balanced scorecard so that it may conform to the culture and values of the public and voluntary sectors addresses some critical success factors for performance management and in the public sectors (Moullin, 2015).

In the past two decades, a lot of innovations have taken place in management accounting and control practices, notably epitomised by notions such as cost/activity-based management under the basis of activity and the balanced scorecard. Traditionally, as a supply-driven phenomenon, bundling has been used by propagators of particular innovations, as by consultants and trade associations, to further attract potential adopters (Ax \& Bjørnenak, 2005). Balanced scorecard and HoshinKanri jointly have been successfully implemented (Asan \& Tanyas, 2007), while Modell (2009) find both BSC and TQM encountered considerable implementation problems. Lawrence and Sharma (2002) argued that although market-based vocabulary, such as TQM and BSC among others, is presumed to introduce efficiency and effectiveness in organisations, their application jeopardises the very essence of education.

\subsection{Criticism for Balance Scorecard}

Since the beginning of BSC, it has evolved from a performance measurement tool to a performance management system (PMS), thanks to the contribution of numerous other authors. There is much confusion in the literature about the exact definition of the balanced scorecard. Due to its widespread use, researchers were enticed to theorise on and test the effectiveness of BSC (Llah et al., 2017). However, the correlation between its four areas of measurement has been questioned (Nørreklit, 2000); for example, the validity of BSC to perform as a strategic management control tool. In addition, a number of issues also appear which may have a connection with the usefulness of BSC as a tool for strategic management.

The evolution of BSC can be attributed to a greater innovation when compared to the original idea by empirical evidence of weakness in the instrument created (Lawrie \& Cobbold, 2004). Early BSCs failed as they pose a major challenge to design appropriately, partly due to the poor characterisation of an effective BSC (Busco \& Quattrone, 2015). Kaplan and Norton were unable to recognise the large body of literature of intangible asset and therefore potentially leading to a confusing classification of such an asset (Marr \&Adams, 2004). The BSC is reported to require financial and non-financial performance measures to be integrated in order to support its purpose, namely strategy implementation, performance 
increase, and strategic decision-making improvement (Kaplan \& Norton, 1992, 1996). Although the BSC may not produce results as expected (Davis and Albright, 2004), the unanticipated effect is often generated, beyond the expectation of its designers (Busco \& Quattrone, 2015). BSC appears to unfold continuously because of the constantly changing rationales for its use (Malmi, 2001; Speckbacher et al., 2003; Busco \& Quattrone, 2015). Nørreklit (2000) argued the ability of BSC as a strategic control tool. Alternatively stated, there is nothing meaningful in studying economic benefits of BSC adoption without taking into account on how they are used. For example, with a purpose of acknowledging the application of BSCs in Finland and why companies adopt them, Malmi (2001) found that connecting measures based on assumed causal relationships were poorly understood by the early adopters of BSC.

Upton and Arrington (2012) discovered tendencies to unintentionally let racial prejudice intervene in the evaluation of balanced scorecard performance. Bessire and Bakker (2005) undertook a critical analysis of balanced scorecard and Tableau de bord, pointing out a complementarity between the two. There is a great expectation that BSC solves many relevance problems related to management accounting and control practices. However, nothing answers the question as to whether BSC really helps to deal with weaknesses as abstraction, shortsightedness, monetary orientation, oversimplification, and lack of focus on intangible factors in the organisation. Thus, there is a need for further discussion and research on this predicament (Johanson et al., 2006). Nørreklit (2003) has a point of view on BSC text, questioning its convincing capabilities and persuasiveness, as well as arguing how it is a feature characteristic of management guru text, how the model it proposes is not so innovative, and how it lacks a reliable theoretical base.

Cooper, Ezzamel and Qu (2017) proposed that it is important to understand that how accounting innovations, such as BSC, are labelled as success or failure influences their development, whether or not they deliver improvements in organisational performance as promised. As the rapid developments of the last decade suggest, the evolution of management accounting concepts appears as if it has failed to follow both developments in technology and business evolution (Nielsen, Lund, \& Thomsen, 2017). Lately, there has been tremendous growth in the business globally. An increasing need for data access and the development of internet-based technology have led to the growth of new business types. Therefore, in due course, BSC has become an outdated means of managerial concept and tool (Voelpel et al., 2006). He stated that BSC has functioned as what is called a "straitjacket" measurement, being a tyranny putting the survival of firms at risks, interrupting business ecosystem innovation needed most, thus impairing customer value rejuvenation, benefits received by shareholders, other stakeholders, as well as societal benefits in general. Nielsen et al. (2017) introduce a critique of concepts proposed at the time of BSCera over the last 25 years. Whereas, in the last decade, managerial concepts are thriving with business models and new ways of creating value for customers in mind. In fact, performance measurement has been abandoned or less managed since BSC was introduced (Kaplan and Norton, 1992) almost 25 years ago. Their research then contributes in a timely manner to the field of performance measurement in the era 
of disruptive business models, such as Uber, and numerous upcoming financial technology companies.

\section{Summaries and Conclusion}

Since the BSC was first created by Kaplan and Norton (1992), there has been a lot of confusion about the exact definition of the balanced scorecard. Several criticisms and questions about the balanced scorecard approach arise. This study aims to review the BSC literature from articles published in the first rank Scopus indexed journal (Q1). Although a large number of academics are sceptical about the relationship between BSC and organisational outcomes, BSC is widely used, and practitioner-oriented literature shows that it has useful values especially in improving organisational performance and strategy attainment. Based on the findings of empirical results in the private sector, SMEs, and the public sector, it can be inferred that out of 45 articles of empirical research of the organisations investigated in terms of the balanced scorecard implementation,14 (31 per cent) gained a high level of success, 6 (13 per cent) failed, and 56 per cent were not representative as the methodology and data collection were not detailed enough. These results conclude the implementation status of the balanced scorecard shows a high level of success and a little of failure.

BSC has limitations, yet these findings show that BSC is beneficial enough. It is reinforcing the view that the BSC remains worth considering for a performance management system. This literature review is limited to the specific quality ratings of academic journals. Studies from other quality ratings from academic journals or conference presentations may have been ignored. Furthermore, other exclusion criteria, namely search restrictions, might lead to ignoring some relevant research.

\section{References}

Ahn, H. (2005). How to individualise your Balanced Scorecard?. Measuring Business Excellence, 9(1), 5-12. https:// doi:10.1108/13683040510588792

AndjelkovicPesic, M., \& Dahlgaard, J.J. (2013). Using the Balanced Scorecard and the European Foundation for quality management excellence model as a combined roadmap for diagnosing and attaining excellence. Total Quality Management \& Business Excellence, 24(5-6), 652663.https://doi.org/10.1080/14783363.2013.791109

Antonsen, Y. (2014). The downside of the Balanced Scorecard: A case study from Norway. $\begin{array}{llll}\text { Scandinavian Journal } & \text { Management, }\end{array}$ https:// doi.org/10.1016/j.scaman.2013.08.001

Asan, S.Ş., \& Tanyaş, M. (2007). Integrating HoshinKanri and the balanced scorecard for strategic management: The case of higher education. Total Quality Management, 18(9), 999-1014. https://doi.org/10.1080/14783360701592604

Atkinson, H. (2006). Strategy implementation: a role for the balanced scorecard?.Management Decision, 44(10), 1441-1460. https:/ / doi:10.1108/00251740610715740

Ax, C., \& Bjørnenak, T. (2005). Bundling and diffusion of management accounting innovations the case of the balanced scorecard in Sweden. Management Accounting Research, 16(1), 1-20. https:// doi.org./10.1016/j.mar.2004.12.002

Banker, R.D., Chang, H., \& Pizzini, M.J. (2004). The balanced scorecard: Judgmental effects of performance measures linked to strategy. The Accounting Review, 79(1), 1-23. https:// doi.org/10.2308/accr.2004.79.1.1

Barnabè, F. (2011). A "system dynamics-based Balanced Scorecard" to support strategic decision making: Insights from a case study. International Journal of Productivity and Performance Management, 60(5), 446-473. https:/ /doi:10.1108/17410401111140383 
Basu, R., Little, C., \& Millard, C. (2009). Case study: A fresh approach of the Balanced Scorecard in the Heathrow Terminal 5 project. Measuring Business Excellence, 13(4), 22-33, https://doi:10.1108/13683040911006765

Basuony, M.A.K. (2014). The Balanced Scorecard in Large Firms and SMEs: A Critique of the Nature, Value and Application. Accounting and Finance Research, 3 (2), 14-22. https:// doi.org/10.5430/afr.v3n2p14

Behery, M., Jabeen, F., \& Parakandi, M. (2014). Adopting a contemporary performance management system: A fast-growth small-to-medium enterprise (FGSME) in the UAE. International Journal of Productivity and Performance Management, 63(1), 22-43. https:// doi.org/10.1108/IJPPM-07-2012-0076

Bento, R.F., Mertins, L., \& White, L.F. (2017). Ideology and the balanced scorecard: An empirical exploration of the tension between shareholder value maximization and corporate social responsibility. Journal of Business Ethics, 142(4), 769-789. https:/ / doi:10.1007/s10551-016-30536

Bessire, D., \& Baker, C.R. (2005). The French Tableau de bord and the American Balanced Scorecard: a critical analysis. Critical Perspectives on Accounting, 16(6), 645-664. https://doi:10.1016/j.cpa.2004.01.004

Bose, S., \& Thomas, K. (2007). Applying the balanced scorecard for better performance of intellectual capital. Journal of intellectual capital, 8(4), 653-665. https:// doi.org/10.1108/14691930710830819

Brignall, S. (2002). The Unbalanced Scorecard: A social and environmental critique. Proceedings of the Performance Measurement Association Conference, $3^{\text {rd }}, \quad 85-92$. https:/ / diblokdcma.files.wordpress.com/2009/08/unbalanced-scorecard.pdf

Budde, J. (2007). Performance measure congruity and the balanced scorecard. Journal of Accounting Research, 45(3), 515-539. https:// doi:10.1111/j.1475-679X.2007.00246.x

Busco, C., \& Quattrone, P. (2015). Exploring how the Balanced Scorecard engages and unfolds: Articulating the visual power of accounting inscriptions. Contemporary Accounting Research, 32(3), 1236-1262. https:// doi:10.1111/1911-3846.12105

Chang, W.C., Tung, Y.C., Huang, C.H., \& Yang, M.C. (2008). Performance improvement after implementing the Balanced Scorecard: A large hospital's experience in Taiwan. Total Quality Management, 19(11), 1143-1154. https:/ / doi.org/10.1080/14783360802323560

Chen, T.Y., Chen, C.B., \& Peng, S.Y. (2008). Firm operation performance analysis using data envelopment analysis and balanced scorecard: A case study of a credit cooperative bank. International Journal of Productivity and Performance Management, 57(7), 523-539. https://doi.org/10.1108/17410400810904010

Chen, Y., Jermias, J., \& Panggabean, T. (2016). The role of visual attention in the managerial Judgment of Balanced-Scorecard performance evaluation: Insights from using an eyetracking device. Journal of accounting research, 54(1), 113-146. https://doi:10.1111/1475679X.12102

Cheng, M.M., \& Humphreys, K.A. (2012). The differential improvement effects of the strategy map and scorecard perspectives on managers' strategic judgments. The Accounting Review, 87(3), 899-924. https://doi.org/10.2308/accr-10212

Chiang, C.Y., \& Lin, B. (2009). An integration of balanced scorecards and data envelopment analysis for firm's benchmarking management. Total Quality Management, 20(11), 1153-1172. https://doi.org/10.1080/14783360903248286

Cooper, D.J., Ezzamel, M., \& Qu, S.Q. (2017). Popularizing a management accounting idea: The case of the balanced scorecard. Contemporary Accounting Research, 34(2), 991-1025. https:// doi.org/10.1111/1911-3846.12299

Craig, J., \& Moores, K. (2005). Balanced scorecards to drive the strategic planning of family firms. Family Business Review, 18(2), 105-122. https:/ / doi.org/10.1111\%2Fj.1741-6248.2005.00035.x

Davis, S., \& Albright, T. (2004). An investigation of the effect of balanced scorecard implementation on financial performance. Management Accounting Research, 15(2), 135-153. https://doi:10.1016/j.mar.2003.11.001

Dinesh, D., \& Palmer, E. (1998). Management by objectives and the Balanced Scorecard: will Rome fall again?. Management Decision, 36(6), 363-369. https:// doi.org/10.1108/00251749810223529 
Ding, S., \& Beaulieu, P. (2011). The role of financial incentives in balanced scorecard-based performance evaluations: Correcting mood congruency biases. Journal of Accounting Research, 49(5), 1223-1247. https:// doi:10.1111/j.1475-679X.2011.00421.x

Dror, S. (2008). The Balanced Scorecard versus quality award models as strategic frameworks. Total Quality ManagementE Business Excellence, 19(6), 583-593. http:/ / dx.doi.org/10.1080/14783360802024366

Elbanna, S., Eid, R., \& Kamel, H. (2015). Measuring hotel performance using the balanced scorecard: A theoretical construct development and its empirical validation. International Journal of Hospitality Management, 51, 105-114. https:/ / doi.org/10.1016/j.ijhm.2015.09.004

Ennas, G., \& Di Guardo, M.C. (2015). Features of top-rated gold open access journals: An analysis

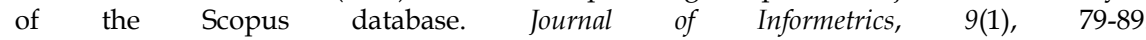
https://doi.org/10.1016/j.joi.2014.11.007

Galindo, G., Yie, R.D., Ditta, A., Ruiz, M., \& Varela, A. (2018). Gender difference in publication among recent OR/MS scientific publications in top journals. Revista ESPACIOS, 39(47). http://www.revistaespacios.com/a18v39n47/18394720.html

Garengo, P., \&Biazzo, S. (2012). Unveiling strategy in SMEs through balanced scorecard implementation: A circular methodology. Total Quality Management $\mathcal{E}$ Business Excellence, 23(1), 79-102. https:// doi.org/10.1080/14783363.2011.637800

Gumbus, A., \& Lussier, R.N. (2006). Entrepreneurs use a balanced scorecard to translate strategy into performance measures. Journal of Small Business Management, 44(3), 407-425. https://doi.org/10.1111/j.1540-627X.2006.00179.x

Gumbus, A., \& Lyons, B. (2002). The balanced scorecard at Philips Electronics. Strategic FinanceMontvale, 84 , $45-49$. https://pdfs.semanticscholar.org/78d1/83e58794f5a5f7de3768a1353a8cdca539a1.pdf

Gurd, B., \& Gao, T. (2007). Lives in the balance: an analysis of the balanced scorecard (BSC) in healthcare organizations. International Journal of Productivity and Performance Management, 57(1), 6-21, 1741-0401. https:// doi:10.1108/17410400810841209

Gurd, B., \& Ifandoudas, P. (2014). Moving towards agility: the contribution of a modified balanced scorecard system. Measuring Business Excellence, 18(2), 1-13. https://doi.org/10.1108/MBE10-2012-0052

Hansen, E.G., \& Schaltegger, S. (2016). The sustainability balanced scorecard: A systematic review of architectures. Journal of Business Ethics, 133(2), 193-221. https://doi:10.1007/s10551-0142340-3

Hoque, Z. (2003). Total quality management and the balanced scorecard approach: a critical analysis of their potential relationships and directions for research. Critical Perspectives on Accounting, 14(5), 553-566. https:/ / doi:10.1016/S1045-2354(02)00160-0

Hoque, Z. (2014). 20 years of studies on the balanced scorecard: trends, accomplishments, gaps and opportunities for future research. The British accounting review, 46(1), 33-59. https://doi.org/10.1016/j.bar.2013.10.003

$\mathrm{Hu}$, Y., Wen, J., \& Yan, Y. (2015). Measuring the performance of knowledge resources using a value perspective: integrating BSC and ANP. Journal of Knowledge Management, 19(6), 12501272. https:// doi.org/10.1108/JKM-10-2014-0431

Ittner, C.D., Larcker, D.F., \& Meyer, M.W. (2003). Subjectivity and the weighting of performance measures: Evidence from a balanced scorecard. The Accounting Review, 78(3), 725-758. https:// doi.org/10.2308/accr.2003.78.3.725

Jayashree, P., \& Jamal H.S. (2011). Aligning change deployment: A Balanced Scorecard approach. Measuring Business Excellence, 15(3), 63-85. https:// doi.org/10.1108/13683041111161166

Johanson, U., Skoog, M., Backlund, A., \& Almqvist, R. (2006). Balancing dilemmas of the balanced scorecard. Accounting, Auditing and Accountability Journal, 19(6), 842-857. https:// doi.org/10.1108/09513570610709890

Kang, J.S., Chiang, C.F., Huangthanapan, K., \& Downing, S. (2015). Corporate social responsibility and sustainability balanced scorecard: The case study of family-owned hotels. International Journal of Hospitality Management, 48, 124-134. https:/ / doi.org/10.1016/j.ijhm.2015.05.001

Kaplan, R.S., \& Norton, D.P. (1992). The balanced scorecard - Measures that drive performance. Harvard

Business

Review

(January-February),

71-79. 
http:/ / planuba.orientaronline.com.ar/wp-content/uploads/2010/03/harvard-businessreview-kaplan-norton-the-balanced-scorecard-measures-that-drive-performance.pdf

Kaplan, R.S. \& Norton, D.P. (1996). The Balanced Scorecard: Translating Strategy into Action. Boston, MA: Harvard Business School Press

Kaplan, R.S. \& Norton, D.P. (2001). The Strategy Focused Organization, Boston: Harvard Business School Press.

Kaplan, R.S. \& Norton, D.P. (2004). The Strategy Map: Guide to Aligning Intangible Assets. Strategy and Leadership, 32(5), 10-17. https://doi.org/10.1108/10878570410699825

Kurtzman, J. (1997). Is Your Company Off Course? Now You Can Find out Why. Fortune, .128130.

http:/ /archive.fortune.com/magazines/fortune/fortune_archive/1997/02/17/222180/ind ex.htm

Lawrence, S., \& Sharma, U. (2002). Commodification of education and academic labour - using the balanced scorecard in a university setting. Critical Perspectives on Accounting, 13(5-6), 661677. https://doi:10.1006/cpac.2002.0562

Lawrie, G., \& Cobbold, I. (2004). Third-generation balanced scorecard: evolution of an effective strategic control tool. International Journal of Productivity and Performance Management, 53(7), 611-623, 1741-0401. https:/ / doi:10.1108/17410400410561231

Letza, S.R. (1996). The design and implementation of the balanced business scorecard: An analysis of three companies in practice. Business Process Re-engineering and Management Journal, 2(3), 54-76.https:// doi.org/10.1108/14637159610151217

Ling S.K., \& Chye K.H. (2001). Balanced scorecard: a rising trend in strategic performance $\begin{array}{lllll}\text { measurement. } \quad \text { Measuring } & \text { Business }\end{array}$ https:// doi.org/10.1108/13683040110397248

Lipe, M. G., \& Salterio, S. E. (2000). The balanced scorecard: Judgmental effects of common and unique performance measures. The Accounting Review, 75(3), 283-298. https://doi.org/10.2308/accr.2000.75.3.283

Llach, J., Bagur, L., Perramon, J., \& Marimon, F. (2017). Creating value through the balanced scorecard: how does it work?. Management Decision, 55(10), 2181-2199. https:// doi.org/10.1108/MD-11-2016-0812

Malagueño, R., Lopez-Valeiras, E., \& Gomez-Conde, J. (2018). Balanced scorecard in SMEs: effects on innovation and financial performance. Small Business Economics, 51(1), 221-244. https:// doi:10.1007/s11187-017-9921-3

Malmi, T. (2001). Balanced scorecards in Finnish companies: a research note. Management Accounting Research, 12(2), 207-220. https:// doi.org/10.1006/mare.2000.0154

Marr, B., \& Adams, C. (2004). The balanced scorecard and intangible assets: similar ideas, $\begin{array}{llll}\text { unaligned } & \text { concepts. } & \text { Measuring Business Excellence, } & \text { 8(3), }\end{array}$ https:// doi.org/10.1108/13683040410555582

Marr, B., \& Schiuma, G. (2003). Business performance measurement-past, present and future. Management Decision, 41(8), 680-687. https:// doi.org/10.1108/00251740310496198

Massingham, R., Massingham, P.R., \& Dumay, J. (2019). Improving integrated reporting: a new learning and growth perspective for the balanced scorecard. Journal of Intellectual Capital, 20(1), 60-82. https://doi.org/10.1108/JIC-06-2018-0095

Mehralian, G., Nazari, J.A., Nooriparto, G., \& Rasekh, H.R. (2017). TQM and organizational performance using the balanced scorecard approach. International Journal of Productivity and Performance Management, 66(1), 111-125. https:/ / doi.org/10.1108/IJPPM-08-2015-0114

Mistry, J. (2003). Performance measurement in the ecommerce industry. Journal of Business and

$\begin{array}{lccc}\text { Economics } & \text { Research, } & 1(11), & 33- \\ \text { https://clutejournals.com/index.php/JBER/article/download/3067/3115 }\end{array}$

Modell, S. (2009). Bundling management control innovations: A field study of organisational experimenting with total quality management and the balanced scorecard. Accounting, Auditing and Accountability Journal, 22(1), 59-90. https:// doi.org/10.1108/09513570910923015

Moullin, M. (2017). Improving and evaluating performance with the Public Sector Scorecard. International Journal of Productivity and Performance Management, 66(4), 442-458. https:// doi.org/10.1108/IJPPM-06-2015-0092 
Mouritsen, J., Thorsgaard Larsen, H., \& Bukh, P. N. (2005). Dealing with the knowledge economy: intellectual capital versus balanced scorecard. Journal of Intellectual Capital, 6(1), 8-27. https://doi.org/10.1108/14691930510574636

Neely, A., Kennerley, M., \& Martinez, V. (2004). Does the balanced scorecard work: An empirical investigation?. Presented at the European Operations Management Association (EurOMA) International Conference, Fontainebleau, 27-29. https:// pdfs.semanticscholar.org/40cc/00af42a4f4ffc11f09ecf3101dd7b2205664.pdf?_ga=2.8 7235800.1535796086.1579230772-1351810714.1564589877

Nielsen, C., Lund, M., \& Thomsen, P. (2017). Killing the balanced scorecard to improve internal disclosure. Journal of Intellectual Capital, 18(1), 45-62. https://doi.org/10.1108/JIC-02-20160027

Norreklit, H. (2000). The balance on the balanced scorecard a critical analysis of some of its assumptions. Management Accounting Research, 11(1), 65 88.https://doi.org/10.1006/mare.1999.0121

Nørreklit, H. (2003). The balanced scorecard: what is the score? A rhetorical analysis of the balanced scorecard. Accounting, Organizations and Society, 28(6), 591-619. https:// doi.org/10.1016/S0361-3682(02)00097-1

Othman, R. (2006). Balanced scorecard and causal model development: preliminary findings. Management Decision, 44(5), 690-702. https:/ / doi.org/10.1108/00251740610668923

Othman, R. (2008). Enhancing the effectiveness of the balanced scorecard with scenario planning. International Journal of Productivity and Performance Management, 57(3), 259-266. https://doi.org/10.1108/17410400810857266

Perkins, M., Grey, A., \& Remmers, H. (2014) What do we really mean by "Balanced Scorecard"?.International Journal of Productivity and Performance Management, 63(2), 148-169. https://doi.org/10.1108/IJPPM-11-2012-0127

Perramon, J., Rocafort, A., Bagur-Femenias, L., \& Llach, J. (2016). Learning to create value through the 'balanced scorecard' model: an empirical study. Total Quality Management and Business Excellence, 27(9-10), 1121-1139. https:/ / doi.org/10.1080/14783363.2015.1060853

Rich, V. (2007). Interpreting the balanced scorecard: an investigation into performance analysis $\begin{array}{lllll}\text { and } \quad \text { bias. } & \text { Beasuring }\end{array}$ https://doi.org/10.1108/13683040710740871

Schneider, R., \& Vieira, R. (2010). Insights from action research: implementing the balanced scorecard at a wind-farm company. International Journal of Productivity and Performance Management, 59(5), 493-507. https://doi.org/10.1108/17410401011052904

Soderberg, M., Kalagnanam, S., Sheehan, N.T., \& Vaidyanathan, G. (2011). When is a balanced scorecard a balanced scorecard?. International Journal of Productivity and Performance Management, 60(7), 688-708. https:// doi.org/10.1108/17410401111167780

Speckbacher, G., Bischof, J., \& Pfeiffer, T. (2003). A descriptive analysis on the implementation of balanced scorecards in German-speaking countries. Management Accounting Research, 14(4), 361-388. https://doi.org/10.1016/j.mar.2003.10.001

Sprinkle, G.B., \& Williamson, M.G. (2007). Experimental research in management accounting. In Chapman, C.S., Hopwood, A.G., \& Shields, M.D. (Eds.), Handbook of Management Accounting. Oxford, U.K.: Elsevier.

Tayler, W.B. (2010). The balanced scorecard as a strategy-evaluation tool: The effects of implementation involvement and a causal-chain focus. The Accounting Review, 85(3), 10951117. https:// doi.org/10.2308/accr.2010.85.3.1095

Thakkar, J., Deshmukh, S.G., Gupta, A.D., \& Shankar, R. (2006). Development of a balanced scorecard: an integrated approach of interpretive structural modeling (ISM) and analytic network process (ANP). International Journal of Productivity and Performance Management, 56(1), 25-59. https:// doi.org/10.1108/17410400710717073

Upton, D. R., \& Arrington, C. E. (2012). Implicit racial prejudice against African-Americans in balanced scorecard performance evaluations. Critical Perspectives on Accounting, 23(4-5), 281297. https://doi.org/10.1016/j.cpa.2012.01.002

Urrutia, I. \& Eriksen, S.D. (2005). Application of the balanced scorecard in Spanish private health-

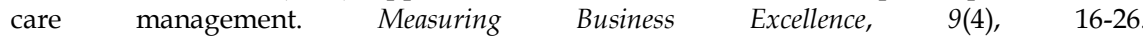
https://doi.org/10.1108/13683040510634808 
Valmohammadi, C., \& Servati, A. (2011). Performance measurement system implementation using Balanced Scorecard and statistical methods. International Journal of Productivity and Performance Management, 60(5), 493-511. https://doi.org/10.1108/17410401111140400

Vermaak, F.N., \&Cronje, C.J. (2001). The balanced scorecard as a potential instrument for supporting the planning and improvement of accounting education in South Africa. Meditari Accountancy Research, 9(1), 301-312. https:// doi.org/10.1108/1022252920010016

Voelpel, S.C., Leibold, M., \& Eckhoff, R.A. (2006). The tyranny of the Balanced Scorecard in the innovation economy. Journal of Intellectual Capital, 7(1), 43-60. https:// doi.org/10.1108/14691930610639769

Wang, W. (2005). An evaluation of the Balanced Scorecard® in equity valuation: The case of exchange ratio in the M\&As of Taiwan's financial industry. Journal of Intellectual Capital, 6(2), 206-221. https://doi.org/10.1108/14691930510592807

Wongrassamee, S., Simmons, J.E., \& Gardiner, P.D. (2003). Performance measurement tools: The Balanced Scorecard and the EFQM Excellence Model. Measuring business excellence, 7(1), 1429. https:// doi.org/10.1108/13683040310466690

$\mathrm{Wu}, \mathrm{A}$. (2005). The integration between balanced scorecard and intellectual capital. Journal of Intellectual Capital, 6(2), 267-284. https://doi.org/10.1108/14691930510592843 